\title{
Tetrastichus giffardianus on pupae of Anastrepha in Brazil
}

\author{
Tetrastichus giffardianus em pupas de Anastrepha no Brasil
}

\begin{abstract}
Almerinda Amélia Rodrigues Araújo ${ }^{I^{*}}$ Paulo Roberto Ramalho Silva ${ }^{I I}$ Ranyse Barbosa Querino Silva ${ }^{\text {III }}$ Elizangela Pereira da Silva Sousa ${ }^{\mathrm{I}}$
\end{abstract}

\section{- NOTE -}

ABSTRACT

Tetrastichus giffardianus Silvestri (Hymenoptera: Eulophidae) is recorded for the first time parasitizing Anastrepha obliqua (Macquart) (Diptera: Tephritidae) in fruits of umbucajazeira Spondias sp. (Anacardiaceae) in Brazil.

Key words: parasitoid, fr uit flies, Spondias $s p$.

RESUMO

Tetrastichus giffardianus Silvestri (Hymenoptera: Eulophidae) é registrado pela primeira vez parasitando Anastrepha obliqua (Macquart) (Diptera: Tephritidae) em frutos de umbu-cajazeira Spondias sp. (Anacardiaceae) no Brasil.

Palavras-chave: parasitoide, moscas-das-frutas, Spondias $s p$.

According to the report of COSTA et al. (2005) many braconid (Opiinae) and eulofideos (Tetrastichinae) were taken from Africa to various parts of the world, for biological control programs. Tetrastichus giffardianus Silvestri (Hymenoptera: Eulophidae), a coinobionte parasitoid that oviposits in mature larvae of the hosts, was released in the early $20^{\text {th }}$ century in at least nine countries. In New World was introduced in Argentina, Brazil, Puerto Rico, United States of America (California). This gregarious parasitoid attacks fruit flies of the genus Ceratitis, Dacus and Bactrocera (Diptera: Tephritidae) (NOYES, 2012; LASALLE \& WHARTON, 2002).
In Brazil, the introduction of the parasitoid was first made in 1937, in the state of São Paulo, by Biological Institute, with the purpose of combating the Mediterranean fruit fly, Ceratitis capitata (Wied.). However, since it was not very effective in the mentioned state, it was practically forgotten since 1950 (COSTA et al., 2005). The quoted authors commented that no one knows for sure why T. giffardianus was not analyzed and studied in the country for a period of approximately 60 years after its introduction, but with the intensification of studies on natural enemies of fruit flies in the Northeast of Brazil, it was studied again. In 1999, 2001 and 2005, the parasitoid was obtained from pupae of $\boldsymbol{C}$. capitata in tropical almonds (Terminalia catappa L.) in the city of Vera Cruz, state of Bahia, acerola (Malpighia glabra L.) in Barauna, state of Rio Grande do Norte, and ceriguela (Spondias purpurea L.), in the city of Fortaleza, Ceara (COSTA et al., 2005). It was also rediscovered in 2004 and 2006 in the city of Presidente Prudente, São Paulo, in puparia of $\boldsymbol{C}$. capitata obtained from fruits of some peach orchards (Prunus persica L. Batsch) (MONTES et al., 2011). The purpose of this note is to record the first occurrence of the parasitoid T. giffardianus parasitizing pupae of $A$. obliqua obtained from fruits of umbu-cajazeira Spondias sp. (Anacardiaceae) in the Brazil.

'Programa de Pós-graduação em Agroecologia, Universidade Estadual do Maranhão (UEMA), Av. Lourenço Vieira da Silva, s/n, Cidade Universitária Paulo VI, 65054-970, São Luís, MA, Brasil. E-mail: a.araraujo@bol.com.br. "Corresponding author.

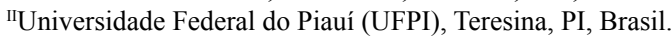

IIIEmbrapa Meio-Norte, Teresina, PI, Brasil. 
The fruits were harvested in a weekly basis in the Teresina, state of Piaui $\left(05^{\circ} 2\right.$ ' 17 "S and $42^{\circ} 47^{\prime} 57^{\prime \prime} \mathrm{W}$ ) from April to July of 2010 , which is the fruiting period for umbu-caja. The fruits were picked in good condition under the canopy of the tree, with the purpose of obtaining puparia. Out of $10.410 \mathrm{~kg}$ of collected biomass (549 fruits), it was obtained 4.464 puparia, with an emergency of 2.297 fruit flies, of which 1.078 were females, all of Anastrepha obliqua specie (Macquart). Three species of parasitoids were found, namely Doryctobracon areolatus (Szépligeti), Opius bellus Gahan (Braconidae) and $\boldsymbol{T}$. giffardianus. The identification of $\boldsymbol{T}$. giffardianus was performed by Ranyse Querino Barbosa, researcher at the Meio-Norte Embrapa, an expert in taxonomy of parasitoids.

In Brazil, T. giffardianus had only been associated with parasitism in $\boldsymbol{C}$. capitata, since its introduction in the country aimed the biological control of this tephritid, being both species originated in Africa. Already the data obtained revealed the parasitism of these parasitoids on a native specie, $A$. obliqua.

According to LASALLE \& WHARTON (2002), in African, these parasitoids often was obtained from fruits of collections which also arose several species of fruit flies. In these circumstances, it was not possible to determine precise relationships of the host. In Hawaii is often registered since it was introduced for the control of Bactrocera dorsalis (Hendel). PURCELL et al. (1996), in reseach to create T. giffardianus in Hawaii, achieved relatively high parasitism rates $(>55 \%)$ for $\boldsymbol{C}$. capitata and lower for B. dorsalis (37\%).
Thus, it can be added to list of tephritids parasitizes by T. giffardianus, Anastrepha obliqua in native fruits Spondia sp.

\section{ACKNOWLEDGEMENTS}

We thank Valmir Antonio Costa, (Instituto Biologico, Campinas, SP, Brasil) for reviewing this manuscript, and Silvano Feitosa Falcão (Warner University - Orlando/FL) for English reviewing.

\section{REFERENCES}

COSTA, V.A. et al. Redescoberta de Tetrastichus giffardianus (Hymenoptera: Eulophidae) após 60 anos da sua introdução no Brasil. Arquivos do Instituto Biológico, v.72, p.539-541, 2005. Available from: <http://www.biologico.sp.gov.br/docs/arq/v72_4/ costa.PDF>. Accessed: Apr. 02, 2012.

LASALLE, J.; WHARTON, R.A. The identity and recognition of African Tetrastichus species (Hymenoptera: Eulophidae) associated with fruit flies (Diptera: Tephritidae). African Entomology, v.10, n.2, p.297-304, 2002. Available from: <http:// www.nhm.ac.uk/resources/research-curation/projects/chalcidoids/ pdf_Y/LaSallWh2002.pdf>. Accessed: Ago. 18, 2015.

MONTES, S.M.N.M. et al. Dinâmica populacional e incidência de moscas-das-frutas e parasitoides em cultivares de pessegueiros (Prunus persica L. Batsch) no município de Presidente Prudente-SP. Revista Brasileira de Fruticultura, v.33, p.402-411, 2011. Available from: $<$ http://www.scielo.br/pdf/rbf/v33n2/AOP04011.pdf $>$. Accessed: Apr. 15, 2012. doi: 10.1590/S0100-29452011005000052.

NOYES, J.S. Universal Chalcidoidea Database. 2012. Available from: <http://www.nhm.ac.uk/research-curation/projects/chalcidoids/>. Accessed: Apr. 02, 2012.

PURCELL, M.F. et al. Bionomics of Tetrastichus giffardianus (Hymenoptera: Eulophidae), an endoparasitoid of tephritid fruit flies. Environmental Entomology, v.25, p.198206, 2996. Available from: <http://ee.oxfordjournals.org/content/25/1/198>. Accessed: Ago. 18, 2015. doi: 10.1093/ee/25.1.198. 